\title{
Farklı Yetiştirme Koşullarının Bazı Ekmeklik Buğday Çeşitlerinin Farinografik Özelliklerine Etkisinin Belirlenmesi
}

\author{
Determination of the Effect of Different Growing Conditions on the Farinograph \\ Characteristics of Some Bread Wheat Varieties
}

\section{Seydi AYDOĞAN*}

Bahri Dağdaş Uluslararası Tarımsal Araştırma Enstitüsü, Konya

seydiaydogan@yahoo.com

iD 0000-0003-0472-1211

\section{Süleyman SOYLU}

Selçuk Üniversitesi Ziraat Fakültesi -Tarla

Bitkileri Bölümü, Konya

ssoylu@selcuk.edu.tr

(iD) 0000-0002-0420-5033

*Sorumlu yazar

Gönderilme Tarihi : 9 Mart 2020

Kabul Tarihi : 10 Mayıs 2020

\section{Özet}

$\mathrm{Bu}$ çalışma, 14 ekmeklik buğday çeşidinin (Gün91, Sönmez-2001, Bezostaya-1, Tosunbey, Pehlivan, Demir-2000, Bayraktar-2000, Gerek-79, Karahan-99, Yunus, Ahmetağa, Konya-2002, Bozkır ve Eraybey) farinograf özelliklerine kuru ve sulu yetiştirme koşullarının etkisini belirlemek amacıyla 2014-2015 yetiştirme döneminde tesadüf blokları deneme desenine göre 2 tekerrürlü olarak Bahri Dağdaş Uluslararası Tarımsal Araştırma Enstitüsünde yürütülmüştür. Ekmeklik buğday çeşitlerinin farinograf parametreleri (gelişme süresi, su absorbsiyonu, stabilite, 10. ve 12. dakika yumuşama değeri) incelenmiştir. Kuru ve sulu koşullarda yetiştirilen çeşitler arasındaki farklar istatistiki olarak değerlendirilmiş̧ir. Farinograf gelişme süresi $(\mathrm{p}<0.001)$, su absorbsiyonu $(\mathrm{p}<0.001)$, stabilite $(p<0.001), 10$. dakika yumuşama değeri $(p<0.001)$ ve 12 . dakika yumuşama değeri $(\mathrm{p}<0.001)$ arasındaki farklar önemli bulunmuştur. Gün-91, Bozkır ve Konya-2002 çeşitlerinde incelenen farinograf özellikleri açısından her iki yetiştirme koşulunda da yüksek değerler belirlenmiştir. Sulu koşullarda gelişme süresi, su absorbsiyonu ve stabilite 
değerlerinin kuru koşullarda elde edilen değerlerden daha yüksek, 10. ve 12. dakika yumuşama değerlerinin ise daha düşük olduğu belirlenmiştir.

Anahtar Kelimeler: Buğday, reoloji, farinograf, su absorbsiyonu, kuru ve sulu koşullar

\section{Abstract}

This study was carried out to determine the effects of rainfed and irrigated growing conditions on farinograph traits of 14 bread wheat varieties (Gün-91, Sonmez-2001, Bezostaya-1, Tosunbey, Pehlivan, Demir-2000, Bayraktar-2000, Requ79, Karahan-99, Yunus, Ahmetaga, Konya-2002, Bozkır, and Eraybey) in 2014-2015 growing period according to randomized block designed with two replications in Bahri Dağdaş International Agricultural Research Institute. Farinograph parameters (development time, water absorption, stability, $10^{\text {th }}$ and $12^{\text {th }}$ minute softening value ) of bread wheats varieties were examined. The differences between the varieties cultivated in rainfed and irrigated conditions were evaluated statistically. The differences between farinograph development time ( $p$ $<0.001)$, water absorption $(\mathrm{p}<0.001)$, stability ( $\mathrm{p}$ $<0.001)$, 10th minute softening value $(\mathrm{p}<0.001)$ and 12 th minute softening value $(\mathrm{p}<0.001)$ were found significant. High values were determined in both growing conditions in terms of the examined farinograph traits in Gün-91, Bozkır and Konya-2002 varieties. It was determined that the development time, water absorption and stability values were higher and the softening values at 10th and 12th minutes were lower in irrigated conditions than rainfed conditions.
Key Words: Wheat, rheology, farinograph, water absorption, rainfed and irrigated conditions

\section{Giriş}

Buğday en çok üretilen ve tüketilen ürün olmasından dolayı dünya ticaretinde önemli bir yere sahiptir. Buğday bilhassa insan beslenmesinin ana temelini olușturmasından dolayı dünyada ve ülkemizde artan nüfusa bağlı olarak ihtiyaçta artmakta, buna bağlı olarak ekim alanları ve birim alandaki tane verimimin artırılması gerekmektedir. Artan ihtiyaca bağlı olarak ıslah çalışmaları hızlanarak amaca uygun yeni çeşitler geliştirmektedirler. Ülkemizde de son yıllarda yüksek verimli ve iyi kalite özeliklerine sahip ekmeklik buğday çeşitleri geliştirilmiş ve üreticilerin hizmetine sunulmuştur. İklim, çevre koşulları ve toprak özellikleri buğdayda kaliteyi oluşturan fiziksel, kimyasal ve teknolojik özelliklere önemli etkisi bulunmaktadır (Atlı, 1999). Ekmeklik buğdaylarda unun protein oranı, su kaldırma kuvveti ve yoğurma toleransının yüksek olması arzu edilmektedir (Ertugay, 1985). Ekmek hacmi protein kalitesine bağlı olup, aynı protein içeriğine sahip unlarda bile farklı performans göstermektedir. Bu nedenle buğday unu kalitesi son ürüne işlenmesine göre tanımlanmalıdır (Carson ve Edwards, 2009). Dinamik bir test olan farinograf testi; unun su absorbsiyonu, hamurun gelişme süresi, stabilite süresi ve yumuşama derecesi gibi parametreleri analiz edebilmekte ve hamur davranışlarının ölçümünde önemli bir yere sahiptir. Ekmeklik kalitesi iyi olan bir unda; su alma kapasitesi, hamurun 
gelişme süresi ve stabilite sürelerinin uzun ve yumuşama derecelerinin ise düşük olması arzu edilmektedir. Hamurun gelişme süresinin uzun olması durumunda yoğurma süresi ve stabilite süresi de uzamakta, hamur elastikiyeti ve işlenmeye uygunluğu yüksek olmakta ve buna bağlı olarak ekmek hacimleri de olumlu yönde etkilenmektedir. Yumuşama derecesinin yüksek olması unun işlenmeye karşı toleransının az ve hamurun fermantasyon süresinin olmasına, hamurun uzun fermantasyona dayanamasına neden olmaktadır (Altan, 1996). Kalite özellikleri çeşide ait bir özellik olsa da yetiştirme koşulları ve iklim faktörlerinden önemli derecede etkilenmektedirler. $\mathrm{Bu}$ çalışma ile farklı yetiştirme koşullarının ekmeklik buğday çeşitlerinin farinograf özelliklerine etkisinin tespit edilmesi ve çeşitlerin performanslarının belirlenmesi amacıyla yürütülmüştür.

\section{Materyal ve Yöntem}

$\mathrm{Bu}$ çalışma bölgemizde ekimi yapılan 14 ekmeklik buğday çeşidinin 2014-2015 yetiştirme döneminde Konya merkez lokasyonunda kuru ve sulu koşullarda tesadüf blokları deneme desenine göre 2 tekerrürlü olarak yürütülmüş ve kalite çalışmalarında her tekerrür için 200 g un kullanılmıştır. Buğday örnekleri, AACC metod 26-95'e göre ( $\% 14.5$ rutubet olacak şekilde) tavlanarak, AACC metod 26-50'ye göre Brabender Junnior değirmende belirlenen randımanda ögütülmüştür (Anonymous, 2000). Kuru koşullar için tescil edilen 8 çeşit (Gün-91, Sönmez-2001, Demir-2000, Bayraktar-2000, Gerek-79, Karahan-99, Bozkır ve Eraybey) ve sulu koşullar için tescil edilen 6 çeşit
(Bezostaya-1, Tosunbey, Pehlivan, Yunus, Ahmetağa, Konya-2002) kullanılmıştır. Kuru koşullarda (550 adet $\left.{ }^{-1} \mathrm{~m}^{2}\right)$ tohum ekilerek taban gübresi olarak $3.5 \mathrm{~kg} \mathrm{~N}$ da $^{-1}$ ve $6.9 \mathrm{~kg} \mathrm{P}_{2} \mathrm{O}_{5} \mathrm{da}^{-1}$ ve üst gübre olarak da $4 \mathrm{~kg} \mathrm{~N} \mathrm{da-1}$ (toplamda $7.5 \mathrm{~kg} \mathrm{~N} \mathrm{da}^{-1}$ ) verilmiştir. Sulu koşullarda (450 $\operatorname{adet}^{-1} \mathrm{~m}^{2}$ ) tohum ekilerek ekimle birlikte $3.5 \mathrm{~kg}$ ${ }^{\mathrm{N}} \mathrm{da}^{-1}$ ve $9 \mathrm{~kg} \mathrm{P}_{2} \mathrm{O}_{5} \mathrm{da}^{-1}$ uygulanmış, bitkilerin kardeşlenme (3.5 $\left.\mathrm{kg} \mathrm{N} \mathrm{da}^{-1}\right)$ ve sapa kalkma (2.5 $\mathrm{kg} \mathrm{N} \mathrm{da}^{-1}$ ) dönemlerinde amonyum nitrat şeklinde gübreleme yapılmıştır. Yetiştirme döneminde toplam $398.70 \mathrm{~mm}$ yağış alınmış ve sulu koşullarda iki defa ek sulama yapılmıştır. Birinci ek su bitkilerin sapa kalkma döneminde (Nisan sonu) $70 \mathrm{~mm}, 2$. ek su ise çiçeklenme öncesi (Mayıs) $70 \mathrm{~mm}$ sulama yapılmış ve denemeler 20 Temmuz da hasat edilmiştir. Araştırmada çeşitlerden elde edilen unların farinograf gelişme süresi, su absorbsiyonu, stabilite, 10. ve 12. dakika yumuşama değerleri AACC 54-21 metoduna göre Farinograf-AT Brabender Germany cihazı ile belirlenmiştir (Anonymous, 2000). Denemelerden elde edilen veriler JMP 11 istatistik programında varyans analizine tabi tutulmuş elde edilen ortalama değerler arasındaki farklılıklar, student çoklu karşılaştırma testi kullanılarak \% 5 önem seviyesinde karşılaştırılmıştır (Anonymous, 2014).

\section{Bulgular ve Tartışma}

\section{Farinograf gelişme süresi}

Farinograf gelişme süresi; hamurun yoğrulması sırasında yoğurucu paletlere göstermiş olduğu direnci dakika olarak belirtmekte olup, kuru koşullarda çeşitlerin gelişme süresi aralığı 2.30 
dk. ile $6.46 \mathrm{dk}$. arasında değişmiş, en yüksek değer Bozkır, en düşük değer ise Sönmez-2001 çeşidinden elde edilmiştir. Denemede yer alan Tosunbey, Ahmetağa, Gün-91, Eraybey ve Yunus çeşitlerinde deneme ortalaması (4.37 dk.) üzerinde gelişme süresi elde edilmiştir. Sulu koşullarda yetiştirilen çeşitlerin gelişme süresi 1.70 ile $14.7 \mathrm{dk}$. arasında değişmiş, en yüksek değer Gün-91, en düşük değer ise Bayraktar-2000 çeşidinde belirlenmiştir (Çizelge 1). Gelişme süresi zayıf unlarda 2 dk.' dan az, orta kuvvetli unlarda 2-3 dk., kuvvetli unlarda 3-5 dk. ve çok kuvvetli unlarda 5-12 dk. olarak bildirilmiştir (Anonymous, 2000). Farinograf gelişme süresi ortalama değerleri karşılaştırıldığında, sulu koşullar kuru koşullara göre $1.27 \mathrm{dk}$. daha yüksek olduğu belirlenmiştir. Gelişme süresinin sulu koşullarda yüksek olmasının tane olum dönemindeki ek sulama ve çeşit özelliğinden kaynaklandığı tahmin edilmektedir. Tane dolum döneminde uygun şartların oluşması tanede protein birikiminin uzamasina ve protein kalitesinin artmasina neden olmaktadır. Benzer bir çalışmada Şahin ve ark. (2017), ekmeklik buğdaylarda sulu koşullarda farinograf gelişme süresi ortalama değerini $6.0 \mathrm{dk}$. olarak belirlemişler, en yüksek değeri Tosunbey (11.33 dk.), en düşük değeri ise Gerek-79 çeșidinde (3.03 dk.) tespit etmişlerdir. Aydoğan ve ark. (2018), farinograf gelişme süresi ortalama değerinin 5.0 ile $15.1 \mathrm{dk}$. sulu koşullarda 4.0 ile $11.1 \mathrm{dk}$. arasında değiştiğini, belirlemişlerdir. Her iki koşul ortalamasına göre gelişme süresi 2.35-10.0 dk. arasında değişmiş, en yüksek değer Gün-91 çeşidinde, en düşük değer ise Gerek-79 çeşidinde elde edilmiştir. Gün-91, Bozkır, Tosunbey, Ahmetağa, Yunus ve
Bezotaya-1 çeşitlerinde deneme ortalaması 5.00 dk. üzerinde farinograf gelişme süresi değerleri belirlenmiştir (Çizelge 1). Farinograf gelişme süresi bakımından çeşitler arasında ve çeşit $\mathrm{x}$ koşullar arasındaki farkın $(\mathrm{p}<0.01)$ düzeyinde istatistiki olarak önemli olduğu tespit edilmiştir (Çizelge 2). Aydoğan ve ark. (2007), Şahin ve ark. (2009), kuru ve sulu şartlarda ekmeklik buğdayda yürüttükleri çalışmalarda çevre etkisinin verim ve kalite özelliklerinde farklılık oluşturduğunu belirlemişlerdir.

\section{Farinograf su absorbsiyonu}

$\mathrm{Su}$ absorsiyonu belirli bir kıvamda hamur elde edebilmek için una katılması gereken su miktarı olup, ekmek yapımında kullanılacak su miktarının yüksek olması arzu edilmektedir. Araştırmada kuru koşullarda çeşitlerin farinograf su absorbsiyonu deneme ortalamas1 \% 59.28 olup, değerler \% 54.35 ile \% 61.93 arasında değişmiş, en yüksek değer Konya-2002, en düşük değer ise Bayraktar-2000 çeşidinde belirlenmiştir. Demir-2000, Sönmez-2001, Bezostaya-1, Bozkır, Yunus ve Tosunbey çeşitlerinde deneme ortalaması (\% 59.29) üzerinde su absorbsiyon değeri elde edilmiştir. Aydoğan ve ark. (2013), kuru koşullarda ekmeklik buğdayda yaptıkları benzer bir çalışmada farinograf su absorbsiyonunun \% 52.60 ile \% 65.90 arasinda değiştiğini, deneme ortalamasının \% 61.20, en yüksek su absorbsiyonunun \% 65.90 ile Dağdaş-94, en düşük su absorbsiyonunun ise \% 52.60 ile Seval çeşidinde olduğunu tespit etmişlerdir. Sulu koşullarda yetiştirilen çeşitlerin su absorbsiyonu \% 53.50-61.60 arasinda değișmiş, deneme ortalaması \% 59.38 olmuş, en yüksek değer Konya-2002, en düşük değer 
Çizelge 1. Ekmeklik buğday çeşitlerinin kuru ve sulu koşullarda farinograf gelişme süresi değerleri

\begin{tabular}{lcccc}
\hline \multicolumn{5}{c}{ Farinograf Gelişme Süresi (dk.) } \\
\hline Çeşitler & Kuru Koşullarda & Sulu Koşullarda & Ortalama & Fark \\
\hline Ahmetağa & $5.44 \mathrm{~b}$ & $7.08 \mathrm{~b}$ & $6.26 \mathrm{bc}$ & 1.64 \\
Bayraktar-2000 & $4.55 \mathrm{~d}$ & $1.70 \mathrm{~h}$ & $3.13 \mathrm{def}$ & 2.85 \\
Bezostaya-1 & $4.36 \mathrm{e}$ & $6.19 \mathrm{c}$ & $5.27 \mathrm{bcd}$ & 1.83 \\
Bozkır & $6.46 \mathrm{a}$ & $7.39 \mathrm{~b}$ & $6.93 \mathrm{~b}$ & 0.93 \\
Demir-2000 & $2.38 \mathrm{f}$ & $3.41 \mathrm{f}$ & $2.90 \mathrm{ef}$ & 1.03 \\
Eraybey & $5.24 \mathrm{c}$ & $6.40 \mathrm{c}$ & $5.82 \mathrm{bc}$ & 1.16 \\
Gerek-79 & $2.38 \mathrm{f}$ & $2.33 \mathrm{~g}$ & $2.35 \mathrm{f}$ & 0.05 \\
Gün-91 & $5.25 \mathrm{c}$ & $14.7 \mathrm{a}$ & $10.0 \mathrm{a}$ & 9.51 \\
Karahan-99 & $4.57 \mathrm{~d}$ & $5.44 \mathrm{~d}$ & $5.00 \mathrm{bcde}$ & 0.87 \\
Konya-2002 & $4.36 \mathrm{e}$ & $4.11 \mathrm{e}$ & $4.23 \mathrm{cdef}$ & 0.25 \\
Pehlivan & $2.33 \mathrm{f}$ & $4.02 \mathrm{e}$ & $3.17 \mathrm{def}$ & 1.69 \\
Sönmez-2001 & $2.30 \mathrm{f}$ & $3.51 \mathrm{f}$ & $2.90 \mathrm{ef}$ & 1.21 \\
Tosunbey & $6.39 \mathrm{a}$ & $7.18 \mathrm{~b}$ & $6.78 \mathrm{~b}$ & 0.79 \\
Yunus & $5.15 \mathrm{c}$ & $5.48 \mathrm{~d}$ & $5.32 \mathrm{bcd}$ & 0.33 \\
\hline Ortalama & 4.37 & 5.64 & 5.00 & 1.27 \\
\hline DK & 7.90 & 3.54 & 3.00 & \\
AÖ\%) & 0.85 & 0.95 & 0.20 & \\
\hline
\end{tabular}

Çizelge 2. Ekmeklik buğday çeşitlerinin kuru ve sulu koşullarda farinograf gelişme süresine ait birleştirilmiş varyans analizi

\begin{tabular}{lcccc}
\hline Varyasyon Kaynağı & Serbestlik Derecesi & Kareler Toplamı & F Değeri & P \\
\hline Çeşit & 13 & 230.67837 & 775.4352 & $<.0001^{* *}$ \\
Koşullar & 1 & 22.69504 & 991.7747 & $<.0001^{* *}$ \\
Tekerrür & 1 & 0.00540 & 0.2361 & 0.6310 \\
Çeşit*Koşul & 13 & 90.97993 & 305.8329 & $<.0001^{* *}$ \\
Hata & 27 & 0.6178 & - & - \\
\hline
\end{tabular}

$*(\mathrm{p}<0.05), * *(\mathrm{p}<0.01)$

ise Bayraktar-2000 çeşidinde belirlenmiştir. Demir-2000, Pehlivan, Sönmez-2001, Tosunbey ve Bozkır çeşitlerinde deneme ortalaması (\% 59.38) üzerinde su absorbsiyonu değeri elde edilmiştir. Yetiştirme koşullarının ortalamalarına göre su absorbsiyonu \% 53.93-61.76 arasında değişmiş, en yüksek değer Konya-2002, en düşük değer Bayraktar-2000 çeşidinde elde edilmiştir (Çizelge 3). Al-Saleh ve Brennan (2012), ekmeklik buğday genotipleri ile sulu koşullarda yapmış oldukları bir çalışmada su absorbsiyon değerinin $\% \quad 56.30$ ile $\% \quad 64.05$ arasında değiştiğini belirlemişlerdir. Şahin ve ark. (2017), sulu koşullarda yaptıkları benzer bir çalışmada su absorbsiyon ortalama değerini \% 60.21 olarak belirlemişler, en yüksek değeri Dağdaş-94 (\% 66.1), en düşük değeri Bayraktar-2000 çeşidinde (\% 54.4) tespit etmişlerdir. Keçeli ve ark. (2017), ekmeklik buğday genotiplerinde farinograf su absorbsiyon ortalama değerinin \% 46.6-66.8 arasında değiştiğini tespit etmişlerdir. Sulu koşullarda su absorbsiyon ortalama değeri kuru koşullardakinden \% 0.10 daha yüksek olmuştur (Çizelge 3). Protein oranı ve kalitesi yüksek unlarda farinograf gelişme süresi ve stabilite değerinin yüksek olması, yumuşama derecesinin ise düşük olması beklenmektedir (Ünal, 1983, Dikici ve ark., 2006, Aydoğan ve ark., 2012). Varyans analizinde çeşitler arasındaki fark $(\mathrm{p}<0.01)$, çeşit $\mathrm{x}$ koşullar 
Çizelge 3. Ekmeklik buğday çeşitlerinin kuru ve sulu koşullarda farinograf su absorbsiyonu değerleri

\begin{tabular}{lllll}
\hline \multicolumn{5}{c}{ Farinograf Su Absorbsiyonu (\%) } \\
\hline Çeşitler & Kuru Koşullarda & Sulu Koşullarda & Ortalama & Fark \\
\hline Ahmetağa & $58.81 \mathrm{ef}$ & $58.89 \mathrm{bcd}$ & $58.78 \mathrm{fg}$ & 0.08 \\
Bayraktar-2000 & $54.35 \mathrm{~g}$ & $53.50 \mathrm{e}$ & $53.93 \mathrm{a}$ & 0.85 \\
Bezostaya-1 & $60.56 \mathrm{bcd}$ & $60.02 \mathrm{abc}$ & $60.29 \mathrm{bcde}$ & 0.54 \\
Bozkur & $59.92 \mathrm{de}$ & $60.22 \mathrm{abc}$ & $60.07 \mathrm{cdef}$ & 0.3 \\
Demir-2000 & $61.75 \mathrm{ab}$ & $61.45 \mathrm{a}$ & $61.60 \mathrm{ab}$ & 0.3 \\
Eraybey & $58.87 \mathrm{ef}$ & $59.32 \mathrm{bcd}$ & $59.09 \mathrm{fg}$ & 0.45 \\
Gerek-79 & $55.56 \mathrm{~g}$ & $57.25 \mathrm{~d}$ & $56.41 \mathrm{~h}$ & 1.69 \\
Gün-91 & $58.50 \mathrm{f}$ & $59.91 \mathrm{abc}$ & $59.20 \mathrm{fg}$ & 1.41 \\
Karahan-99 & $58.82 \mathrm{ef}$ & $59.32 \mathrm{~cd}$ & $59.07 \mathrm{~g}$ & 0.5 \\
Konya-2002 & $61.93 \mathrm{a}$ & $61.60 \mathrm{a}$ & $61.76 \mathrm{a}$ & 0.33 \\
Pehlivan & $60.25 \mathrm{~cd}$ & $61.25 \mathrm{ab}$ & $60.75 \mathrm{abcd}$ & 1 \\
Sönmez-2001 & $61.17 \mathrm{abc}$ & $61.11 \mathrm{ab}$ & $61.14 \mathrm{abc}$ & 0.06 \\
Tosunbey & $59.6 \mathrm{def}$ & $60.32 \mathrm{abcd}$ & $59.96 \mathrm{defg}$ & 0.72 \\
Yunus & $59.91 \mathrm{de}$ & $57.15 \mathrm{~d}$ & $58.53 \mathrm{~g}$ & 2.76 \\
\hline Ortalama & 59.28 & 59.38 & 59.22 & 0.10 \\
\hline DK(\%) & 4.96 & 3.26 & 1.5 & \\
AÖF(0.05) & 0.91 & 1.25 & 1.28 & \\
\hline
\end{tabular}

Çizelge 4. Ekmeklik buğday çeşitlerinin kuru ve sulu koşullarda farinograf su absorbsiyonuna ait birleştirilmiş varyans analizi

\begin{tabular}{lcccc}
\hline Varyasyon Kaynağı & Serbestlik Derecesi & Kareler Toplamı & F Değeri & P \\
\hline Çeşit & 13 & 230.62091 & 20.9968 & $<.0001^{* *}$ \\
Koşullar & 1 & 0.25650 & 0.3036 & 0.5862 \\
Tekerrür & 1 & 1.86150 & 2.2032 & 0.1493 \\
Çeşit*Koşul & 13 & 15.74312 & 1.4333 & $0.0177^{*}$ \\
Hata & 27 & 22.8121 & - & - \\
\hline
\end{tabular}

$*(\mathrm{p}<0.05), * *(\mathrm{p}<0.01)$

arasındaki fark ise $(p<0.05)$ düzeyinde önemli bulunmuştur (Çizelge 4). Karaduman (2013) yapmış olduğu bir çalışmada farinograf su absorbsiyon değerinin sulu koşullarda kuru koşullardan daha yüksek olduğunu belirlemiştir.

\section{Farinograf 10. dakika yumuşama değeri}

Farinograf yumuşama değerinin düşük olması arzu edilen bir durum olup, hamurun kalitesine bağlı olarak yoğurucu paletlerin vermiş olduğu durum olarak bilinmektedir. Yumuşama değerleri düşük olan unların Brabeender Unit (BU) değeri 151 den büyük, orta kuvvetli unların 30140 arasında ve kuvveti unların 30 dan küçük, çok kuvveti unların ise " 0 " olmaları gerektiği bildirilmiştir (Anonymous, 2000). Kuvvetli gluten yapısına sahip unların yumuşama değeri düşük olmaktadır. Araştırmada kuru koşullarda çeşitlerin 10. dk. yumuşama değeri 12.5 ile 89.0 BU arasında değişmiş, en yüksek yumuşama değeri Demir-2000, en düşük değer ise Gün91 çeşidinden elde edilmiştir. Aydoğan ve ark. (2013) kuru koşullarda 10. dk, yumuşama değerinin 3.00 ile $31.00 \mathrm{BU}$ arasında değiştiğini, en düşük değerin 3.0 BU ile Sönmez-2001, en yüksek değerin 31.00 BU ile Süzen-97 çeşidinde olduğunu belirlemişlerdir. Sulu 
koşullarda yetiştirilen çeşitlerin farinograf 10 . dk. yumuşama değeri 3.00-48.00 BU arasında değişmiş, en yüksek değer Demir-2000, en düşük değer ise Gün-91 çeşidinde elde edilmiştir. Farinograf 10. dk. yumuşama değeri bakımından yetiştirme koşullarının ortalama değerleri karşılaştırıldığında, kuru koşullarda bu değerin suluya göre yüksek olduğu belirlenmiștir (Çizelge 5). Yetiştirme koşullarının ortalama değerlerine göre 10. dk. yumuşama değeri 7.6068.5 arasında değişmiş, deneme ortalaması 32.93 BU olarak tespit edilmiştir. Hem sulu hem de kuru koşullarda en düşük 10. dk. yumuşama değeri Gün-91 çeşidinde belirlenmiş, yetiştirme koşulları ve çeşitlere göre yumuşama değerlerinin değiştiği tespit edilmiştir. Çeşitler arasındaki fark $(\mathrm{p}<0.01)$, çeşit $\mathrm{x}$ koşullar arasındaki fark ise $(p<0.01)$ düzeyinde istatistiki olarak önemli bulunmuştur (Çizelge 6).

\section{Farinograf 12. dakika yumușama değeri}

Kuru koşullarda çeşitlerin 12. dk. yumuşama değeri 27.5 ile $130 \mathrm{BU}$ arasında değişmiştir. Deneme ortalaması 71.75 BU olup, en yüksek değer Demir-2000 çeşidinde, en düşük değer ise Bozkır çeşidinde belirlenmiştir. Sulu koşullarda yetiştirilen çeşitlerin farinograf 12 . dk. yumuşama değeri 15.5 ile $124 \mathrm{BU}$ arasında değişmiş, deneme ortalaması 50.96 BU olarak tespit edilmiştir. En yüksek değer Gerek-79, en düşük değer ise Bayraktar-2000 çeşidinde

Çizelge 5. Ekmeklik buğday çeşitlerinin kuru ve sulu koşullarda farinograf 10. dakika yumuşama değerleri

\begin{tabular}{lcccc}
\hline \multicolumn{5}{c}{ Farinograf 10. dakika Yumuşama(BU) } \\
\hline Çeşitler & Kuru Koşullarda & Sulu Koşullarda & Ortalama & Fark \\
\hline Ahmetağa & $31.0 \mathrm{efg}$ & $16.0 \mathrm{fg}$ & $23.5 \mathrm{~cd}$ & 15 \\
Bayraktar-2000 & $30.5 \mathrm{fg}$ & $12.5 \mathrm{~g}$ & $21.5 \mathrm{~cd}$ & 18 \\
Bezostaya-1 & $37.0 \mathrm{def}$ & $7.50 \mathrm{~h}$ & $22.2 \mathrm{~cd}$ & 29.5 \\
Bozkır & $13.0 \mathrm{~h}$ & $14.0 \mathrm{~g}$ & $13.5 \mathrm{~d}$ & 1 \\
Demir-2000 & $89.0 \mathrm{a}$ & $48.0 \mathrm{~b}$ & $68.5 \mathrm{a}$ & 41 \\
Eraybey & $22.5 \mathrm{~g}$ & $21.0 \mathrm{de}$ & $21.7 \mathrm{~cd}$ & 1.5 \\
Gerek-79 & $44.5 \mathrm{~d}$ & $41.5 \mathrm{a}$ & $43.0 \mathrm{a}$ & 3 \\
Gün-91 & $12.5 \mathrm{~h}$ & $3.00 \mathrm{l}$ & $7.60 \mathrm{~d}$ & 9.5 \\
Karahan-99 & $30.5 \mathrm{fg}$ & $19.0 \mathrm{ef}$ & $24.7 \mathrm{bcd}$ & 11.5 \\
Konya-2002 & $39.5 \mathrm{de}$ & $38.8 \mathrm{c}$ & $39.15 \mathrm{bc}$ & 0.7 \\
Pehlivan & $53.5 \mathrm{c}$ & $38.0 \mathrm{c}$ & $45.7 \mathrm{~b}$ & 15.5 \\
Sönmez-2001 & $67.5 \mathrm{~b}$ & $25.0 \mathrm{~d}$ & $46.2 \mathrm{~b}$ & 42.5 \\
Tosunbey & $27.0 \mathrm{~g}$ & $21.0 \mathrm{de}$ & $24.0 \mathrm{~cd}$ & 6 \\
Yunus & $38.5 \mathrm{def}$ & $19.0 \mathrm{ef}$ & $28.75 \mathrm{bcd}$ & 19.5 \\
\hline Ortalama & 38.32 & 23.21 & 32.93 & 15.11 \\
\hline DK & 8.6 & 6.75 & 8.36 & \\
AÖF) & 4.02 & 4.08 & 4.38 & \\
\hline
\end{tabular}

Çizelge 6. Ekmeklik buğday çeşitlerinin kuru ve sulu koşullarda farinograf 10. dakika yumuşama değerine ait birleștirilmiș varyans analizi

\begin{tabular}{lcccc} 
Varyasyon Kaynağı & Serbestlik Derecesi & Kareler Toplamı & F Değeri & P \\
\hline Çeşit & 13 & 27150.857 & 145.8997 & $<.0001^{* *}$ \\
Koşullar & 1 & 6048.643 & 422.5443 & $<.0001^{* *}$ \\
Tekerür & 1 & 31.500 & 2.2005 & 0.1495 \\
Çeşit*Koşul & 13 & 10825.357 & 58.1719 & $<.0001^{* *}$ \\
Hata & 27 & 386.500 & - & - \\
\hline
\end{tabular}


elde edilmiştir. Yetiştirme koşullarının 12. dk. yumuşama değeri bakımından ortalama değerleri karşılaştırıldığında, kuru koşullarda bu değerin suluya göre 20.79 BU yüksek olduğu tespit edilmiştir (Çizelge 7). Yumuşama değerinin yüksek olması gluten kalitesinin düşük olmasının bir göstergesi olarak kabul edilmekte ve yoğrulma sirasinda hamurun yoğurucu paletlere göstermiş olduğu direnç düşük olmaktadır. Mikos ve Podolska (2012) yüksek yumuşama derecesinin düşük hamur stabilitesini gösterdiğini bildirmişlerdir. Karaduman (2013), gluten kuvvetini gösteren değerler ile farinograf yumuşama değeri arasında negatif korelasyon olduğunu belirlemiştir. Yetiştirme koşullarının ortalamasına göre 12. dk. yumuşama değeri deneme ortalaması 61.36 BU olup, her iki koşulda en yüksek değer Demir-2000 çeşidinde elde edilmiş, varyans analiz sonuçlarına göre çeşitler ve çeşit $\mathrm{x}$ koşullar arasındaki fark $(\mathrm{p}<0.01)$ düzeyinde istatistiki olarak önemli bulunmuştur. Varga ve ark. (2003), yapmış oldukları bir çalışmada farinograf 12. dk. yumuşama değerine yıl, çeşit ve yılxçeşit interaksiyonunun etkisinin $(\mathrm{p}<0.05)$ düzeyinde önemli bulunduğunu bildirmişlerdir.

\section{Farinograf Stabilite}

Kuvvetli özellikteki unların hamur gelişme süresi ve stabilitesinin yüksek olması,

Çizelge 7. Ekmeklik buğday çeşitlerinin kuru ve sulu koşullarda farinograf 12. dakika yumuşama değerleri

\begin{tabular}{lllll}
\hline \multicolumn{5}{c}{ Farinograf 12. dakika Yumuşama(BU) } \\
\hline Çeşitler & Kuru Koşullarda & Sulu Koşullarda & Ortalama & Fark \\
\hline Ahmetağa & $63.5 \mathrm{f}$ & $46.0 \mathrm{def}$ & $54.7 \mathrm{cde}$ & 17.5 \\
Bayraktar-2000 & $51.5 \mathrm{~g}$ & $15.5 \mathrm{~g}$ & $33.5 \mathrm{ef}$ & 36.0 \\
Bezostaya-1 & $87.5 \mathrm{~d}$ & $40.0 \mathrm{ef}$ & $63.7 \mathrm{~cd}$ & 47.5 \\
Bozkır & $27.5 \mathrm{i}$ & $38.5 \mathrm{f}$ & $33.0 \mathrm{ef}$ & 11.0 \\
Demir-2000 & $130 \mathrm{a}$ & $78.0 \mathrm{~b}$ & $104 \mathrm{a}$ & 52.5 \\
Eraybey & $47.0 \mathrm{~g}$ & $54.5 \mathrm{~cd}$ & $50.0 \mathrm{def}$ & 7.5 \\
Gerek-79 & $76.0 \mathrm{e}$ & $124 \mathrm{a}$ & $100 \mathrm{ab}$ & 48.0 \\
Gün-91 & $34.0 \mathrm{~h}$ & $20.0 \mathrm{~g}$ & $27.0 \mathrm{f}$ & 14.0 \\
Karahan-99 & $63.5 \mathrm{f}$ & $45.0 \mathrm{def}$ & $54.2 \mathrm{de}$ & 18.5 \\
Konya-2002 & $96.5 \mathrm{c}$ & $60.5 \mathrm{c}$ & $78.5 \mathrm{bc}$ & 36.0 \\
Pehlivan & $75.0 \mathrm{e}$ & $59.5 \mathrm{c}$ & $67.2 \mathrm{~cd}$ & 15.5 \\
Sönmez-2001 & $104 \mathrm{~b}$ & $42.5 \mathrm{ef}$ & $73.2 \mathrm{~cd}$ & 61.5 \\
Tosunbey & $67.5 \mathrm{f}$ & $48.5 \mathrm{de}$ & $58.0 \mathrm{~cd}$ & 19.0 \\
Yunus & $80.5 \mathrm{e}$ & $41.0 \mathrm{ef}$ & $60.7 \mathrm{~cd}$ & 39.5 \\
\hline Ortalama & 71.75 & 50.96 & 61.36 & 20.79 \\
\hline DK & 4.05 & 7.12 & 6.11 & \\
AÖF) & 2.88 & 9.84 & 5.34 & \\
\hline
\end{tabular}

Çizelge 8. Ekmeklik buğday çeşitlerinin kuru ve sulu koşullarda farinograf 12. dakikadaki yumuşama değerlerine ait birleştirilmiş varyans analizi

\begin{tabular}{lcccc}
\hline Varyasyon Kaynağı & Serbestlik Derecesi & Kareler Toplamı & FDeğeri & P \\
\hline Çessit & 13 & 27150.857 & 145.8997 & $<.0001^{* *}$ \\
Koşullar & 1 & 6048.643 & 422.5443 & $<.0001^{* *}$ \\
Tekerür & 1 & 31.500 & 2.2005 & 0.1495 \\
Çeşit*Koşul & 13 & 10825.357 & 58.1719 & $<.0001^{* *}$ \\
Hata & 27 & 386.500 & - & - \\
\hline
\end{tabular}


yumuşama derecesinin düşük olması ile karakterize edilmekte, zayıf unlar ise hızlica zayıflamakta ve sonuçta yüksek yumuşama derecesine sahip olmaktadirlar (Shahzadi ve ark., 2005). Hamur stabilite süresinin, zayıf unlarda 4 dk.' dan az, orta kuvvette unlarda 4 ile 7 dk., kuvvetli unlarda 7 ile 14 dk., çok kuvvetli unlarda ise 14 dk.'dan uzun olması gerektiği belirlenmiştir (Anonymous, 2000). Araştırmada kuru koşullarda çeşitlerin farinograf stabilite değeri 3.96-13.6 dk. arasında değişmiş, en yüksek değer Gün-91, en düşük değer ise Demir-2000 çeşidinde tespit edilmiştir. Çeşitleri genel olarak incelediğimizde Bayraktar-2000, Eraybey, Gün-91, Ahmetağa, Tosunbey ve Karahan-99 çeşitlerinde deneme ortalaması 8.66 dk. üzerinde stabilite elde edilmiştir. Aydoğan ve ark. (2013), kuru koşullarda farinograf stabilite değerinin $2.35 \mathrm{dk}$. ile $20 \mathrm{dk}$. arasında değiştiğini tespit etmişlerdir. Sulu koşullarda yetiştirilen çeşitlerin farinograf stabilite değeri 5.37-19.0 $\mathrm{dk}$. arasında değişmiş, deneme ortalaması 11.38 dk. olarak belirlenmiștir. Sulu koşularda en yüksek değer Gün-91 çeşidinde elde edilmiştir. Çeşitleri genel olarak incelediğimizde Bozkır, Ahmetağa, Karahan-99, Yunus, Bezostaya-1 ve Tosunbey çeşitlerinde deneme ortalaması 11.38 dk. üzerinde stabilite değeri elde edilmiştir. Sulu şartlarda ortalama farinograf stabilite değerinin kuru şartlara göre $2.72 \mathrm{dk}$. daha yüksek olduğu belirlenmiştir (Çizelge 9). Çeşitler ve çeşit $x$ koşullar arasındaki farkın $(\mathrm{p}<0.01)$ düzeyinde istatistiki olarak önemli olduğu tespit edilmiştir (Çizelge 10). Her iki koşul ortalamasına göre

Çizelge 9. Ekmeklik buğday çeşitlerinin kuru ve sulu koşullarda farinograf stabilite değerleri

\begin{tabular}{|c|c|c|c|c|}
\hline \multicolumn{5}{|c|}{ Farinograf Stabilite (dk.) } \\
\hline Cesitler & Kuru Kosullarda & Sulu Kosullarda & Ortalama & Fark \\
\hline Ahmetağa & $11.1 \mathrm{c}$ & $14.8 \mathrm{c}$ & $12.9 \mathrm{~b}$ & 3.73 \\
\hline Bayraktar-2000 & $12.9 \mathrm{~b}$ & $7.77 \mathrm{f}$ & $10.3 \mathrm{bcd}$ & 5.2 \\
\hline Bezostaya-1 & $7.59 \mathrm{e}$ & $12.7 \mathrm{~d}$ & $10.1 \mathrm{bcd}$ & 5.15 \\
\hline Bozkır & $8.25 \mathrm{e}$ & $16.8 \mathrm{~b}$ & $12.5 \mathrm{~b}$ & 8.63 \\
\hline Demir-2000 & 3.961 & $6.52 \mathrm{fg}$ & $5.24 \mathrm{f}$ & 2.56 \\
\hline Eravbey & $11.0 \mathrm{c}$ & $10.8 \mathrm{e}^{8}$ & $10.9 \mathrm{bc}$ & 0.28 \\
\hline Gerek-79 & $6.40 \mathrm{~g}$ & $5.37 \mathrm{~g}$ & $5.88 \mathrm{ef}$ & 1.03 \\
\hline Gün-91 & $13.6 \mathrm{a}$ & $19.0 \mathrm{a}$ & $16.3 \mathrm{a}$ & 5.34 \\
\hline Karahan-99 & $10.2 \mathrm{~d}$ & $13.7 \mathrm{~cd}$ & $11.9 \mathrm{~b}$ & 3.45 \\
\hline Konya-2002 & $8.53 \mathrm{e}$ & $8.06 \mathrm{f}$ & $8.30 \mathrm{cde}$ & 0.47 \\
\hline Pehlivan & $5.09 \mathrm{~h}$ & $7.11 \mathrm{f}$ & $6.10 \mathrm{ef}$ & 2.02 \\
\hline Sönmez-2001 & $4.15_{1}$ & $10.8 \mathrm{e}$ & $7.47 \mathrm{def}$ & 6.65 \\
\hline Tosunbey & $9.81 \mathrm{~d}$ & $12.4 \mathrm{~d}$ & $11.1 \mathrm{bc}$ & 2.63 \\
\hline Yunus & $8.39 \mathrm{e}$ & $13.2 \mathrm{~d}$ & $10.8 \mathrm{bc}$ & 4.83 \\
\hline Ortalama & 8.66 & 11.38 & 10.02 & 2.72 \\
\hline $\mathbf{D K}_{(\%)}$ & 3 & 5.32 & 5.4 & \\
\hline AÖF) & 1.25 & 1.57 & 0.76 & \\
\hline
\end{tabular}

Çizelge 10. Ekmeklik buğday çeşitlerinin kuru ve sulu koşullarda farinograf stabilitesine ait birleştirilmiş varyans analizi

\begin{tabular}{lcccc} 
Varyasyon Kaynağı & Serbestlik Derecesi & Kareler Toplamı & FDeğeri & P \\
\hline Çeşit & 13 & 506.26117 & 129.5555 & $<.0001^{* *}$ \\
Koşullar & 1 & 103.22430 & 343.4049 & $<.0001^{* *}$ \\
Tekerür & 1 & 0.50730 & 1.6877 & 0.2049 \\
Çeşit*Koşul & 13 & 165.56437 & 42.3690 & $<.0001^{* *}$ \\
Hata & 27 & 8.11595 & - & - \\
\hline
\end{tabular}


stabilite değeri $10.02 \mathrm{dk}$. olup, en yüksek değer Gün-91 çeşidinden elde edilmiştir. Sulu ve kuru koşullarda Gün-91, Bozkır, Ahmetağa, Karahan-99, Eraybey, Yunus, Bezostaya-1 ve Tosunbey çeşitlerinde deneme ortalamas 10.02 dk. üzerinde stabilite değerleri belirlenmiştir (Çizelge 9).

\section{Sonuç}

$\mathrm{Bu}$ çalışmada ekmeklik buğday çeşitlerinin farinograf özelliklerinin farklı yetiştirme koşullarındaki (kuru ve sulu) değişimi ve denemede yer alan çeşitlerin performansları tespit edilmeye çalışılmıştır. Çalışma sonucunda; sulu koşullarda yetiștirilen ekmeklik buğday çeşitlerinde farinograf gelişme süresi, stabilite ve su absorbsiyonu bakımından daha yüksek değerler elde edilmiştir. 10. ve 12. dk. yumuşama değerleri ise kuru koşullarda daha yüksek olmuştur. Yetiştirme koşullarının ortalama değerlerine bakıldığında; farinograf gelişme süresi ve stabilite değerleri bakımından Gün91, su absorbsiyonu bakımından Konya-2002 çeşitlerinde en yüksek değer elde edilmiştir. 10 . dk. ve 12. dk. yumuşama değerleri bakımından en düşük değer Gün-91 çeşidinde belirlenmiştir. Kuru ve sulu yetiştirme koşullarının farinograf özelliklerini doğrudan ve dolaylı olarak etkilediği görülmüştür. Çeşitlerin kalite özellikleri çeşit özelliği olsa da iklim ve çevre faktörlerinin buğday kalitesine önemli etkisi bulunmaktadır. Konya yöresi için hem kuru hem de sulu yetiştirme koşullarının ortalama değerleri incelendiğinde farinograf özellikleri bakımından Gün-91, Bozkır, Konya-2002 çeşitlerinin yüksek değer verdiği tespit edilmiştir. Bu çeşitlerde her iki koşulda yüksek değerlerin elde edilmesi ile bölgede ekiminin yapılmasının uygun olup, sanayicinin ve firınciların istenen kalite değerlerine ulaşması konusunda yardımcı olacağı düşünülmektedir.

\section{Kaynaklar}

Al-Saleh, A., Brennan, C.S., 2012. Bread wheat quality: Some physical, chemical and rheological characteristics of syrian and english bread wheat samples. Foods. 2012 Dec; 1(1): 3-17.

Altan, A., 1996. Tahıl işleme teknolojisi, Çukurova Üniversitesi Ziraat Fakültesi Ofset Atölyesi, Adana.

Anonymous, 2000. Approved methods of the American Sssociation of Cereal Chemist, Methot no: 54-21, USA.

Anonymous, 2014. JMP11, Js1 Syntax Reference. Sas Institute, Isbn:978-1-62959-560-3.

Atlı, A., 1999. Buğday ve ürünleri kalitesi. Orta Anadolu'da hububat tarımının sorunları ve çözüm yolları sempozyumu, S. 498506, 8-11 Haziran 1999, Konya.

Aydoğan S., Göçmen Akçacık A., Şahin M. ve Kaya Y., 2007. Ekmeklik Buğday (T.aestivum L.) Genotiplerinde Verim ve Bazı Kalite Özellikleri Arasındaki İlişkiler. Tarla Bitkileri Merkez Araştırma Enstitüsü Dergisi. 16 (1-2): 21-31 Ankara. Aydoğan, S., Akçacik, A. G., Şahın, M., Kaya, Y., Koç, H., Görgülü, M. N., 2012. Ekmeklik Buğday Unlarında Alveograf, Farinograf ve Miksografta Ölçülen Reolojik Özellikler Arasındaki İlişkinin Belirlenmesi, SDÜ Ziraat Fakültesi Dergisi, 7 (1): 74-82.

Aydoğan, S., Göçmen Akçacık, A., Şahin, M., Önmez, H., Demir, B., Yakışır, E., 
2013. Ekmeklik buğday çeşitlerinde fizikokimyasal ve reolojik özelliklerin belirlenmesi. Tarla Bitkileri Merkez Araştırma Enstitüsü Dergisi, 22(2): 74-85. Aydoğan, S., Şahin, M., Göçmen Akçacık, A, Demir, B., Hamzaoğlu, S., Taner, S., 2018. Determining the diversity of bread wheat variteties on yield and quality traits at rainfed and irrigated conditions. Selcuk J Agr. Food Sci, 32(2): 170-173.

Carson, G.R., Edwards, N.M., 2009. Criteria of Wheat and Flour Quality. Wheat Chemistry and Technology Editors Khalil Khan and Peter R. Shewry s:108. Fourth edition AACC International Inc. St.Paula

Dikici, N., Bilgiçli, N., Elgün, A.,Ertaş, N., 2006. "Unun Ekmekçilik Kalitesi ile Farklı Metotlarla Ölçülen Hamur Reolojik Özellikleri Arasındaki İlişkiler," Gıda Dergisi, vol. 31.

Ertugay, Z., 1985. Buğday unu sınıflandırılmasında dikkate alınan ölçüler, Standard Ekonomik ve Teknik Dergisi, Özel Sayı 2: 81-85.

Karaduman, Y., 2013. Seçilmiş yumuşak ekmeklik buğday hatlarında bisküvilik kalite özelliklerinin araştırılması. Doktora Tezi, Ankara Üniversitesi Fen Bilimleri Enstitüsü.

Keçeli, A., Kaplan Evlice, A., Pehlivan, A., Şanal, T., Karaca, K., Külen, S., Seis Subaşı, A., Salantur, A., 2017. Ekmeklik Buğdayda (Triticum aestivum L.) Zeleny sedimantasyon analizi ve diğer kalite paramatreleri ile ilişkisinin incelenmesi. KSÜ Doğa Bilimleri Dergisi. 20(Özel Say1): 292-296.
Mikos, M., Podolska, G., 2012. Bread-making quality of old common bread (Triticum aestivum ssp. vulgare L) and spelt (Triticum aestivum ssp. spelta L.) Wheat Cultivars. Journal of Food, Agriculture and Environment, Vol.10, Iss. (3 and 4): 221-224.

Shahzadi, N., Butt, M.S., Rehman, S.U., Sharif, K., 2005. Rheological and baking performance of composite flours. International Journal of Agriculture and Biology, 7(1): 100-104.

Şahin M., Aydoğan S., Akçacık Göçmen A., Taner S., 2009. Orta Anadolu için geliştirilmiş bazı ekmeklik buğday genotiplerinin alveograf enerji değeri yönünden değerlendirilmesi. Bahri Dağdaş Uluslararası Tarımsal Araştırma Enstitüsü Bitkisel Araştırma Dergisi 2: 1-9. Konya. Şahin, M., Göçmen Akçacık, A., Aydoğan, S., Hamzaoğlu, S., Demir, B., Yakışır, E., 2017. Kışlık ekmeklik buğday çeşitlerinde Zeleny sedimantasyon ile verim ve bazı kalite özellikleri arasındaki ilişkilerin incelenmesi. Tarla Bitkileri Merkez Araştırma Enstitüsü Dergisi, 26(1):86-95.

Ünal, S. S., 1983. "Hububat Teknolojisi” Ege Üniversitesi Mühendislik Fakültesi Yayınları.

Varga, B., Svecnjak, Z., Jurkovic, Z., Kovacevic, J., Jukic, Z., 2003. Wheat grain and flour quality as affected by cropping intensity. Food Technology and Biotechnology, 41(4): 321-329. 